\title{
Erratum to: Artificial super intelligence: beyond rhetoric
}

\author{
Karamjit S. Gill ${ }^{1}$
}

Published online: 7 April 2016

(c) Springer-Verlag London 2016

\section{Erratum to: AI \& Soc \\ DOI 10.1007/s00146-016-0651-x}

The word 'supper' in the title as well as in the text has been replaced by the word 'super' in this erratum in order to avoid any unintended misunderstanding of the use of the word 'supper' in the original publication. The article has been updated accordingly.

The online version of the original article can be found under doi:10.1007/s00146-016-0651-x.

Karamjit S. Gill

editoraisoc@yahoo.co.uk

1 Professor Emeritus, University of Brighton, Brighton, UK 